\title{
Development of compound microsatellite markers in the toxic dinoflagellate Alexandrium catenella (Dinophyceae)
}

\author{
Goh Nishitani ${ }^{1}$, Satoshi Nagai ${ }^{1 *}$, Estelle Masseret ${ }^{2}$, Chunlian Lian $^{3}$, Sanae Yamaguchi $^{1}$, \\ Nina Yasuda ${ }^{4}$, Shigeru Itakura ${ }^{1}$, Daniel GrzebyK $^{2}$, Patrick Berrebi $^{5} \&$ Masashi SeKino $^{6}$ \\ ${ }^{1}$ Harmful Algal Bloom Division, National Research Institute of Fisheries and Environment of Inland Sea, Maruishi 2-17-5, \\ Hatsukaichi, Hiroshima 739-0452, Japan \\ ${ }^{2}$ University Montpellier 2, Laboratoire Ecosystèmes Lagunaires (UMR-CNRS 5119, ECOLAG), cc93, Place Eugene Bataillon, \\ 34095 Montpellier Cedex 05, France \\ ${ }^{3}$ Asian Natural Environmental Science Center, the University of Tokyo, 1-1-8 Midori-cho, Nishitokyo-shi, Tokyo 188-0002, \\ Japan \\ ${ }^{4}$ Graduate School of Information Science and Engineering, Tokyo Institute of Technology, O-okayama 2-12-1, Meguro-ku, Tokyo \\ 152-8552, Japan \\ ${ }^{5}$ University Montpellier 2, Institut des Sciences de l'Evolution (UMR-CNRS 5554), cc065, Place Eugene Bataillon, 34095 \\ Montpellier Cedex 5, France \\ ${ }^{6}$ Tohoku National Fisheries Research Institute, Shinhama, Shiogama, Miyagi, 985-0001, Japan
}

Received 22 March 2007; Accepted 7 May 2007

\begin{abstract}
In this study, we identified 9 polymorphic compound microsatellite markers in the toxic dinoflagellate Alexandrium catenella, which was isolated from Thau lagoon (France, Mediterranean Sea), using the compound microsatellite marker technique. These new microsatellites were characterized by screening DNA templates from 43 A. catenella clonal strains, which were collected from a seawater sample from Inokushi Bay (Oita Prefecture, Japan). These loci provide one class of highly variable genetic marker: the number of alleles ranged from 3 to 8 , and the estimate of gene diversity varied between 0.285 and 0.762 . We also analyzed the same 43 DNA samples using microsatellite markers previously identified for $A$. catenella, comparing the PCR amplification success, the number of alleles and gene diversity. These three parameters were not significantly different, showing that the compound microsatellite markers have the same potential to reveal $A$. catenella genetic structure. This simple and efficient method reduces the costs for developing SSR markers and for analyzing the genetic structure of populations, therefore, suggesting the effectiveness of applying this method to other species.
\end{abstract}

Key words: Alexandrium catenella, microsatellite, phytoplankton, SSR markers, toxic dinoflagellate

\section{Introduction}

The genus Alexandrium comprises a closely related cosmopolitan toxigenic group of morphologically similar species, which is called the Alexandrium tamarense "species complex", including Alexandrium tamarense (Lebour) Balech, A. catenella (Whedon \& Kofoid) Balech and $A$. fundyense Balech. Within this species complex, five or six distinct ribotypes/geographic clades have been identified from phylogenetic analysis of the D1/D2 region in the LSU rDNA: western European, North American, temperate Asian, Tasmanian, tropical Asian, and Mediterranean clades (Scholin et al. 1995, John et al. 2003). These authors

* Corresponding author: Satoshi Nagai; E-mail, snagai@affrc.go.jp also demonstrated that North American and Japanese isolates of $A$. tamarense show a high degree of genetic similarity, as do the rDNA sequences of Australian and Japanese A. catenella. Therefore, it was proposed that the exchange of shellfish stocks between British Columbia and Japan (F. J. R Taylor, personal communication) and frequent shipping from Japan/Korea to Australia or other countries around the world are mechanisms whereby transfers of $A$. tamarense/catenella could occur (Scholin et al. 1995). In 1995, a bloom of Alexandrium sp. was first observed in Thau lagoon, French Mediterranean Sea. In 1998, another bloom leading to high levels of paralytic shellfish toxins detected in shellfish stocks, was attributed to A. catenella (Lilly et al. 2002). Since then, the species has been regularly recorded in the phytoplankton in this area, sometimes 
forming toxic blooms. Lilly et al. (2002) claimed that $A$. catenella was introduced from Japan into Thau lagoon via ballast water, because the sequence of the D1/D2 region in the LSU rDNA and the PCR RFLP pattern was similar to those of the Japanese temperate Asian ribotype of $A$. catenella, and until the late 1990s, the temperate Asian ribotype had not been reported outside the western Pacific. However, rDNA data are insufficient to test the dispersal theories because of insufficient polymorphism (Masseret et al. 2006). Until recently, no genetic marker was available for $A$. catenella that could unambiguously distinguish between indigenous and introduced flora. Thus, the development of highly polymorphic genetic markers was needed to test these theories.

Microsatellites (or Single Sequence Repeats, SSRs) are tandemly repeated motifs of 1-6 bases found in all prokaryotic and eukaryotic genomes investigated to date. They are present in both coding and non-coding regions and are usually characterized by a high degree of length polymorphism. Although their mechanism of evolution remains unclear, soon after their first description (Litt \& Luty 1989, Tautz 1989) SSRs have been widely employed in many fields, because of their high variability, making them very powerful genetic markers for population discrimination.

We consider that an assessment of the genetic relationships among $A$. catenella populations with highly polymorphic genetic markers will provide the most promising approach to detail dispersal mechanisms. Nagai et al. (2006) have already reported 12 polymorphic microsatellite markers for A. catenella. However, to test the hypothesis that $A$. catenella could have been introduced from temperate Asia (e.g., Japan) into Thau lagoon through ballast water or shellfish stocks, additional microsatellite markers are needed. This is because some of the markers gave either too many null alleles, misleading bands, or excrescent ghost bands when a large number of samples were examined. In this study, we identified 9 polymorphic compound microsatellite markers in the toxic dinoflagellate A. catenella using a recently developed isolation technique (Lian et al. 2006, Nishitani et al. in press). We also compared the PCR amplification success (number of non-amplifying samples), the number of alleles and the gene diversity of microsatellite markers developed using different methods to evaluate the performance of the compound SSR primer method.

\section{Materials and Methods}

Total genomic DNA was extracted from three cultures isolated in Thau lagoon (France, Mediterranean Sea) in 2002 from germinated resting cysts (strains ACT1 and ACT2), and in 2003 from vegetative cells (ACT3). Cells were grown in natural seawater medium enriched according to Harrison et al. (1980). Genomic DNA was extracted using a DNeasy Plant Mini Kit (QIAGEN). The compound microsatellites were prepared according to Lian et al. (2006), as depicted in Fig. 1. The DNA was separately di- gested with $A f a \mathrm{I}, A l u \mathrm{I}$ and HaeIII blunt-end restriction enzymes (Fig. 1-A). The DNA fragments were then ligated with a blunt adaptor, consisting of a 48-mer (5'-GTAATACGACTCACTATAGGGCACGCGTGGTCGACGGCCCGGGCTGGT-3') and a 8-mer with the $3^{\prime}$ end capped by an amino residue (5'-ACCAGCCC-NH $\left.{ }_{2}-3^{\prime}\right)$, using a DNA Ligation Kit (TakaraBio, Japan) (Fig. 1-B). This blocks polymerase catalyzed extension of the shorter adaptor strand, preventing the generation of a primer binding site unless a defined, distal, gene-specific primer extends a DNA strand opposite the upper strand of the adapter (Siebert et al. 1995).

To concentrate the microsatellite regions, fragments flanked by a microsatellite at one end were amplified from the constructed libraries by compound SSR primers (AC) 6 $(\mathrm{AG})_{5}$ or $(\mathrm{AC})_{5}(\mathrm{TC})_{7}$ and an adaptor primer AP2 (5'CTATAGGGCACGCGTGGT-3') designed from the longer strand of the adaptor (Fig. 1-C). The amplified fragments were subcloned and sequenced (Fig. 1-D). For each fragment containing $(\mathrm{AC})_{6}(\mathrm{AG})_{\mathrm{n}}$ or $(\mathrm{AC})_{5}(\mathrm{TC})_{\mathrm{n}}$ compound sequences at one end, a specific primer (SP) was designed from the sequenced region flanking the microsatellite and screened (Fig. 1-E). The primer pairs of specific primer (SP) and compound SSR primer were used as a compound microsatellite marker.

To examine the suitability of the 66 primer pairs designed as compound markers, PCRs using the three DNA templates mentioned above were performed on a thermal cycler (PC-808, ASTEC) in a reaction mixture $(10 \mu \mathrm{l})$ containing $1-10 \mathrm{ng}$ of template DNA, $0.2 \mathrm{mM}$ of each dNTP, $1 X$ PCR buffer (10mM Tris- $\mathrm{HCl}, 50 \mathrm{mM} \mathrm{KCl}, \mathrm{Mg}^{2+}$ free, $\mathrm{pH}$ 8.3, Applied Biosystems), $2.5 \mathrm{mM}$ of $\mathrm{Mg}^{2+}, 0.25 \mathrm{U}$ of Ampli Taq Gold (Applied Biosystems) and $0.5 \mu \mathrm{M}$ of each SP and a TAMRA-labelled compound primer $(\mathrm{AC})_{6}(\mathrm{AG})_{5}$ or $(\mathrm{AC})_{5}(\mathrm{TC})_{7}$. PCR cycling conditions were as follows: 9 min at $94^{\circ} \mathrm{C}, 38$ cycles of $30 \mathrm{~s}$ at $94^{\circ} \mathrm{C}, 30 \mathrm{~s}$ at the primerspecific annealing temperature (Table 1), and $45 \mathrm{~s}$ at $72^{\circ} \mathrm{C}$, and a final elongation of $5 \mathrm{~min}$ at $72^{\circ} \mathrm{C}$. To characterize the candidate microsatellites, we screened DNA samples from 43 A. catenella clonal strains isolated from Inokushi Bay (Oita Prefecture, Japan), in 2006. The PCR products were denatured at $95^{\circ} \mathrm{C}$ for $5 \mathrm{~min}$, and electrophoresed on $6 \%$ Long Ranger sequencing gels (Cambrex Bio Science) using a Gel-Scan 3000 (Corbett Robotics). The size of alleles was determined according to a size marker (GeneScan 350, Applied Biosystems) with the ONE DSCAN EX version 3.02 software (Scanalytics).

\section{Results and Discussion}

Nine of the 66 primer pairs were selected, the other 57 being rejected because of the low level of genetic variation or the occurrence of unexpected PCR bands. The characteristics of 9 compound microsatellites are described in Table 1. Each of these loci showed a single band in each individual, consistent with the haploid genome of this species. Six 


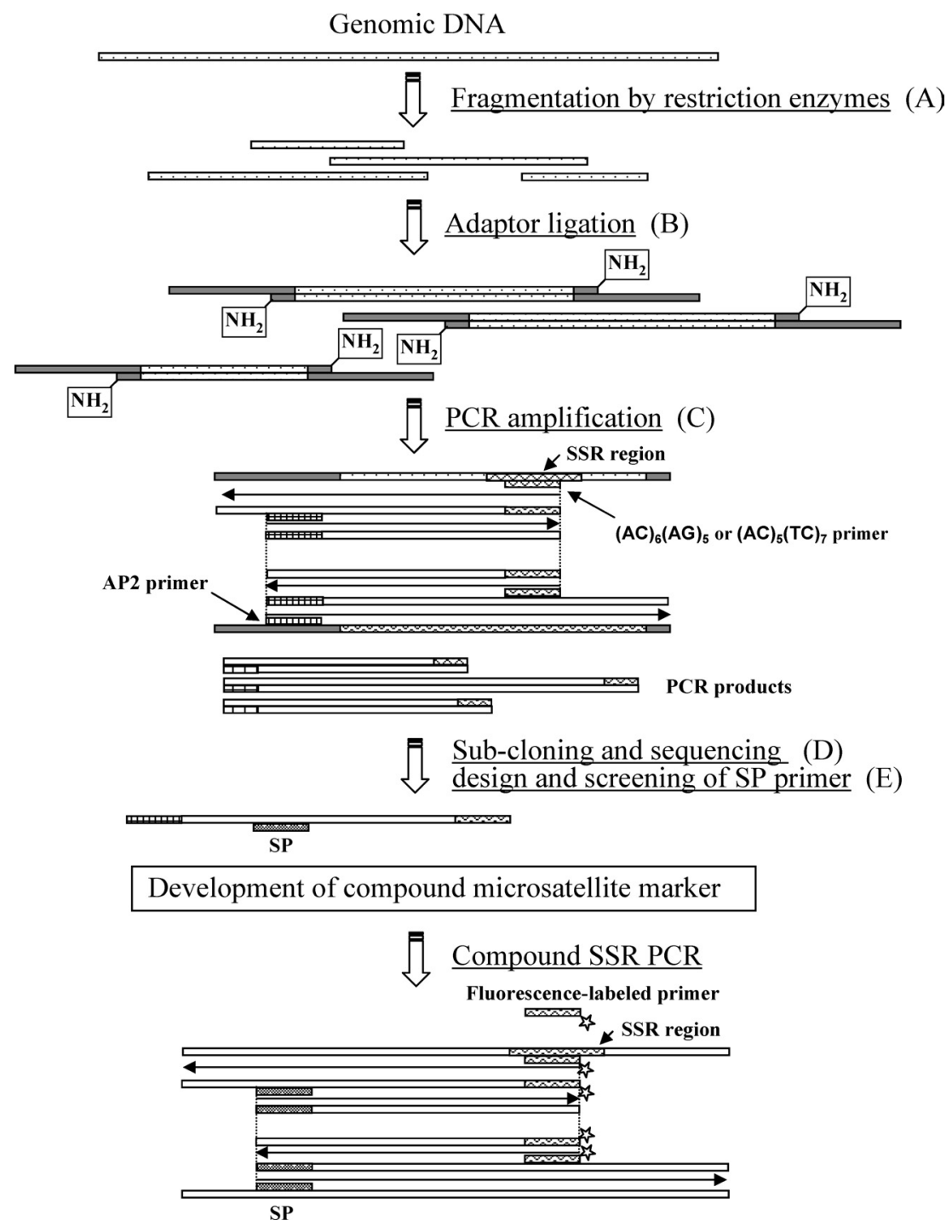

Fig. 1. Schematic representation for developing compound microsatellite markers (Lian et al. 2006). The basic procedure of this method is as follows; A) digestion of genomic DNA with blunt-end restriction enzymes, B) adaptor ligation of fragmented DNAs with an unequal length adaptor, C) enrichment of compound SSR regions by PCR amplification using compound SSR primers and an adaptor primer, D) sub-cloning and sequencing of the compound SSR regions amplified by the PCR, E) design and screening of SP primers as microsatellites.

loci (FMAC06, FMAC08, FMAC09, FMAC16, FMAC49 and FMAC55) occasionally yielded no visible PCR band in some individuals, possibly due to the presence of null alleles at these loci. Linkage disequilibrium for all pairs of loci was tested with GENEPOP version 3.4 available on the web (Raymond \& Rousset 1995): no significant linkage disequilibrium was found. Numbers of non-amplifying samples were $0-8$ with an average plus standard deviation of $2.0 \pm 2.5$. Number of alleles at the 9 loci ranged from 3 to 8 with an average plus standard deviation of $5.2 \pm 1.9$, and the estimate of gene diversity (Nei 1987) varied between 0.285 and 0.762 with an average plus standard deviation of $0.543 \pm 0.177$.

The same 43 DNA samples were analyzed in parallel using 11 microsatellites, out of 12 previously developed for
Alexandrium catenella by Nagai et al. (2006), for comparison with the 9 new compound microsatellite loci. We excluded one of the 12 markers previously reported (Acat44) due to a significant linkage disequilibrium with Acat06. Numbers of non-amplifying samples were $0-19$ with an average plus standard deviation of $4.5 \pm 6.3$. Number of alleles ranged from 1 to 8 with an average plus standard deviation of $4.7 \pm 2.4$, and the estimate of gene diversity (Nei 1987) varied between 0.000 and 0.810 with an average plus standard deviation of $0.550 \pm 0.265$ (Table 2). The three parameters analyzed, using microsatellite markers isolated by the two different methods, were not significantly different according to the Mann-Whitney test, showing that the compound microsatellite markers have the same potential to reveal $A$. catenella genetic structure as have the loci iso- 


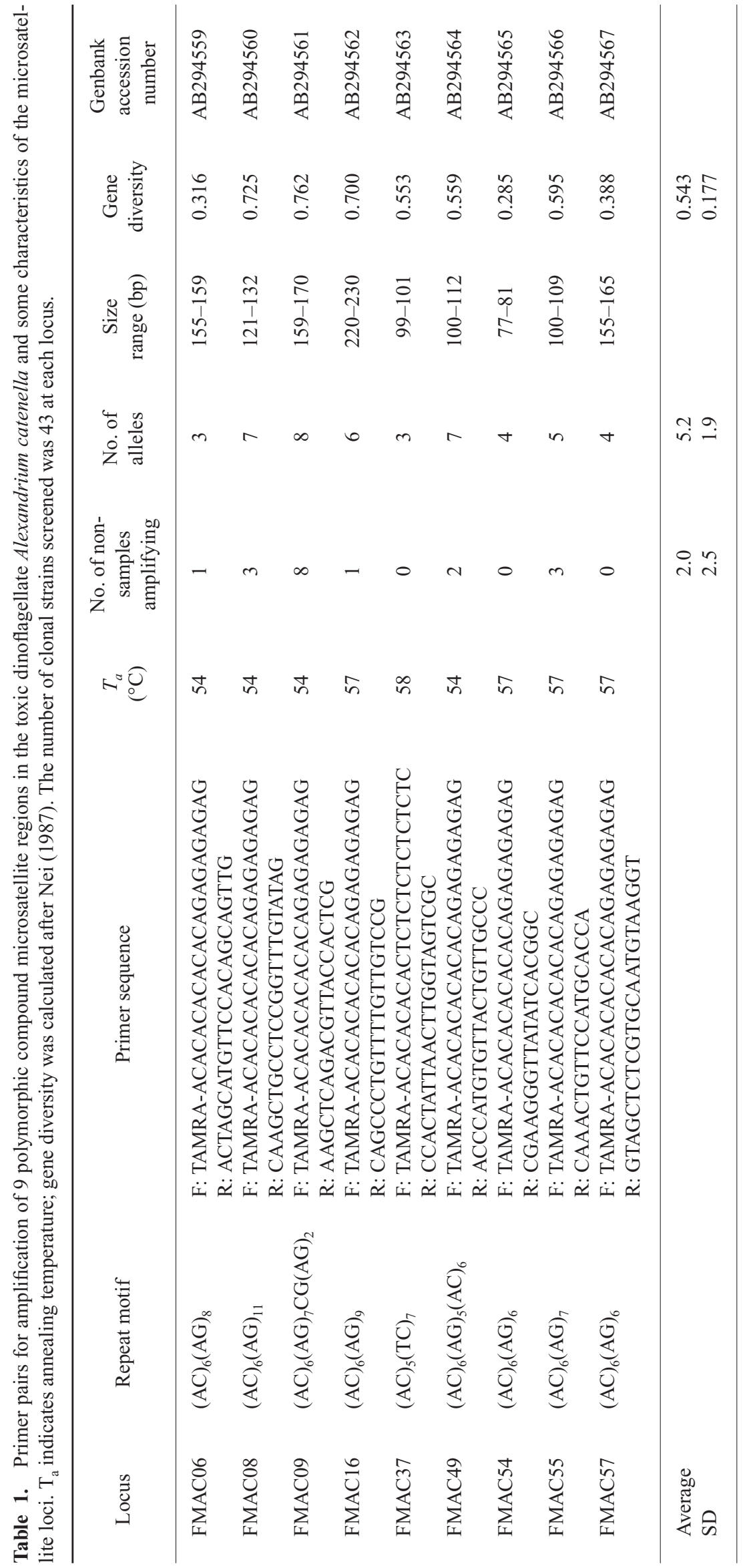


lated by the primer extension method (Nagai et al. 2006). The basic procedure of this method is as follows; 1) genomic DNA fragmentation to a size of 500 to $900 \mathrm{bp}, 2$ ) preparation of single-strand DNAs by helper phages after transformation of fragmented DNAs, 3) construction of a $(\mathrm{CA})_{\mathrm{n}}$-enriched library by primer extension, 4 ) transformation and sequencing of the resultant double-strand DNAs, 5) design and screening of primer pairs as microsatellites (Sekino et al. 2000). By comparing the two methods used for development of microsatellite markers (Table 3), the isolation efficiency was similar in both methods and they were $13.6 \%$ and $12.6 \%$, respectively. The numbers of nonlabeled and fluorescence-labeled primers that we purchased were 66 and 2, respectively, for the compound SSR primer method (the present method), whereas they were $95 \times 2$ and 17 , respectively, for the primer extension method, showing better economic performance for the present method. The time duration needed for the development of microsatellite

Table 2. PCR amplification using the microsatellite primers for Alexandrium catenella previously developed by the primer extension method (Nagai et al. 2006). Gene diversity was calculated after Nei (1987). The number of clonal strains screened was 43 at each locus.

\begin{tabular}{lccc}
\hline Locus & $\begin{array}{c}\text { No. of non- } \\
\text { amplifying } \\
\text { samples }\end{array}$ & $\begin{array}{l}\text { No. of } \\
\text { alleles }\end{array}$ & $\begin{array}{c}\text { Gene } \\
\text { diversity }\end{array}$ \\
\hline Acat02 & 14 & 2 & 0.186 \\
Acat06 & 5 & 8 & 0.810 \\
Acat10 & 5 & 5 & 0.749 \\
Acat14 & 0 & 2 & 0.454 \\
Acat16 & 1 & 6 & 0.789 \\
Acat20 & 19 & 7 & 0.708 \\
Acat22 & 1 & 6 & 0.753 \\
Acat34 & 2 & 7 & 0.641 \\
Acat37 & 0 & 1 & 0.000 \\
Acat49 & 1 & 3 & 0.414 \\
A8cat50 & 1 & 5 & 0.544 \\
\hline Average & 4.5 & 4.7 & 0.550 \\
SD & 6.3 & 2.4 & 0.265 \\
\hline
\end{tabular}

markers in the present method was shorter than that for the primer extension method. However, the present method may not be as effective in some species such as Gymnodinium catenatum Graham due to the low level of genetic variations in compound SSR regions of $(\mathrm{AC})_{6}(\mathrm{AG})_{5}$ or $(\mathrm{AC})_{5}(\mathrm{TC})_{7}$ (Nagai et al. unpublished data). Motifs of $(\mathrm{TC})_{6}(\mathrm{AC})_{5}$ and $(\mathrm{CT})_{6}(\mathrm{CA})_{5},(\mathrm{AC})_{5}(\mathrm{TC})_{7}$ or $(\mathrm{TC})_{5}(\mathrm{TG})_{7}$ were useful in Chattonella species (Raphidophyceae) (Nishitani et al. in press) and the blue coral Heliopora coerulea (Pallas) (Octocorallia) (Yasuda et al. unpublished data), respectively. In conclusion, at least in A. catenella, the compound SSR primer method is a relatively simple, efficient and cheap method for developing SSR markers. Since the method only requires fluorescent labeling of the compound SSR primer for analyzing all related SSR markers, it also reduces the cost for analyzing the genetic structure of populations.

\section{Acknowledgements}

This work was supported by the Fisheries Agency of Japan and the National Research Agency (Grant ANR-05BLAN-0219-01 XpressFlorAl) of France.

\section{References}

Harrison PJ, Waters RE, Taylor FJR (1980) A broad spectrum artificial seawater medium for coastal and open ocean phytoplankton. J Phycol 16: 28-35.

John U, Fensome RA, Medlin LK (2003) The application of a molecular cock based on molecular sequences and the fossil record to explain biogeographic distributions within the Alexandrium tamarense "Species Complex" (Dinophyceae). Mol Biol Evol 20: 1015-1027

Lian CL, Wadud MA, Geng QF, Shimatani K, Hogetsu T (2006) An improved technique for isolating codominant compound microsatellite markers. J Plant Res 119: 415-417.

Lilly EL, Kulis DM, Gentien P, Anderson DM (2002) Paralytic shellfish poisoning toxins in France linked to a human-introduced strain of Alexandrium catenella from the western Pacific: evidence from DNA and toxin analysis. J Plankton Res 24: 443-452.

Litt M, Luty JA (1989) A hypervariable microsatellite revealed by

Table 3. Comparison of two different methods for the development of microsatellite markers in the toxic dinoflagellate Alexandrium catenella.

\begin{tabular}{|c|c|c|c|c|}
\hline Method & $\begin{array}{l}\text { Isolation } \\
\text { efficiency }\end{array}$ & $\begin{array}{c}\text { Number of } \\
\text { primers }\end{array}$ & $\begin{array}{c}\text { Fluorescence } \\
\text { labeled primers }{ }^{\dagger}\end{array}$ & $\begin{array}{l}\text { Duration } \\
\text { (Weeks) }\end{array}$ \\
\hline $\begin{array}{l}\text { Compound SSR primer } \\
\text { method (this study) }\end{array}$ & $9 / 66(13.6 \%)$ & 66 & 2 & 3 \\
\hline $\begin{array}{l}\text { Primer extension method } \\
\text { (Nagai et al. 2006) }\end{array}$ & $12 / 95(12.6 \%)$ & $95 \times 2$ & 17 & 4 \\
\hline
\end{tabular}

\footnotetext{
$\S$, the number of microsatellite markers developed/the number of sequences determined; ${ }^{\ddagger}$, the number of non-labeled primers purchased; ${ }^{\dagger}$, the number of fluorescence-labeled primers purchased; ", the time duration for the development of microsatellite markers starting from DNA extraction until the end of the microsatellite primer screening.
} 
in vitro amplification of a dinucleotide repeat within the cardiac muscle actin gene. Am J Hum Genet 44: 397-401.

Masseret E, Nagai S, Grzebyk D, Genovesi-Giunti B, Lasserre B, Laabir M, Alvirie D, Collos Y, Vaquer A, Berrebi P (2006) Testing the hypothesis of temperate Asia origin of Alexandrium catenella in Thau lagoon (NW Mediterranean) using microsatellite markers. Poster Comm. 12th Intern. Conf. on Harmful Algae, Copenhagen, Denmark, 4-8 sept. 2006.

Nagai S, Sekino M, Matsuyama Y, Itakura S (2006) Development of microsatellite markers in the toxic dinoflagellate Alexandrium catenella (Dinophyceae). Mol Ecol Notes 6: 120-122.

Nei M (1987) Molecular Evolutionary Genetics. Columbia University Press, New York.

Nishitani G, Nagai S, Sakamoto S, Lian CL, Lee CK, Nishikawa T, Itakura S, Yamaguchi M (in press). Development of compound microsatellite markers in the harmful dinoflagellate Cochlodinium polykrikoides (Dinophyceae). Mol Ecol Notes.

Nishitani G, Nagai S, Lian CL, Yamaguchi H, Sakamoto S, Yoshimatsu S, Oyama K, Itakura S, Yamaguchi M (in press). Devel- opment of compound microsatellite markers in the harmful red tide species Chattonella ovata (Raphidophyceae). Mol Ecol Notes.

Raymond M, Rousset F (1995) GENEPOP (version 1.2): population genetics software for exact tests and ecumenicism. J Hered 86: 248-249.

Scholin CA, Hallegraeff GM, Anderson DM (1995) Molecular evolution of the Alexandrium tamarense "species complex" (Dinophyceae): dispersal in the North American and West Pacific regions. Phycol 34: 472-485.

Sekino M, Takagi N, Hara H, Takahashi H (2000) Microsatellites in rockfish Sebastes thompsonii (Scorpaenidae). Mol Ecol Notes 9: 634-636.

Siebert PD, Chenchik A, Kellogg DE, Lukyanov KA, Lukyanov SA (1995) An improved PCR method for walking in uncloned genomic DNA. Nucleic Acids Res 23: 1087-1088.

Tautz D (1989) Hypervariability of simple sequences as a general source for polymorphic DNA markers. Nucleic Acids Res 17: 6463-6471. 